\title{
Measurement and Evaluation in Education by Active Learning for Students in Mathematics Major Usage of Activities Base
}

\author{
C. Waree
}

\begin{abstract}
These The goals are: to develop and discover efficiency of textbook on the subject of Measurement and Evaluation in Education by active learning for students in mathematics major usage of activities base to meet with criteria at $80 / 80$ and to study satisfaction level of students by using the sufficiency economy philosophy textbook for sustainable learning . The target group herein was 40 students who studied in Academic year of 2014 and interested in online registration. Target group was determined by using purposive sampling. Tools used in this research were 20 items of post-test contained in textbook, student's satisfaction evaluation form towards textbook usage. Data analysis was conducted to find efficiency of textbook as defined by criteria at 81.50 / 82.00 and student's satisfaction level towards textbook usage of 40 students. The obtained mean was 4.52 and standard deviation was 0.61 . The results showed that the efficiency of textbook on the subject of Measurement and Evaluation in Education was at 81.50 / 82.00 that was higher than defined criteria at $80 / 80$. In addition, Overall satisfaction of target group was in the highest level with the mean of 4.52 and S.D. at 0.61 .
\end{abstract}

Index Terms-Textbook, measurement and evaluation, active learning, activities base.

\section{INTRODUCTION}

The objective of instructional management of each course and educational measurement and assessment is to enable teachers to have skills in designing learning measurement and assessment therefore they will be able to implement obtained knowledge for improving and developing learning of students. In addition, they will be able to build knowledge on instructional management based on the result of assessment with the following course description: Regulations, principles, and techniques on educational measurement and assessment, creation, usage, and quality inspection of learning measurement and assessment tools, performance assessment, authentic assessment, portfolio assessment, summative and formative assessment, and implementation of assessment results for improving learning management and courses. It can be seen that educational measurement and assessment is considered as an important course for teachers.

From studying the research of Sweller [1], it was found that active learning was suitable with learning objective on learning for comprehension and implementation promoting students to be alert and enthusiastic to think in lieu of listening and memorizing. Consequently, their learning will be more efficient. In addition, students preferred active learning to passive learning. These results were consistent with Renner and Abraham [2] who found that active learning activities enabled students to understand on concepts they learned correctly and deeply leading to good learning connection and retention. Students were amused by challenging and exciting activities enabling them to utilize some important concepts for solving problems, developing answers, and integrating concepts they were learning systematically. Consequently, they were able to adjust their concepts clearly promoting positive attitudes towards learning because they realized on value of learning practiced by them.

It could be seen that most styles of educational management and instructional management for promoting creativity and learning achievement of students are practicing through activity-based learning. This process emphasizes on making students understand via group activities focusing on stimulating students to understand and build knowledge on studied content while performing activities. Consequently, students will be able to develop their own concepts and knowledge. Especially, if those activities are group activities, students will be able to develop their leadership, human relations, team working, and social skills.

From such reason, the researcher was interested in utilizing innovation and electronic media to convey a development of textbook on the subject of Measurement and Evaluation in Education by active learning for students in mathematics major usage of activities base.

\section{OBJECTIVES}

To develop textbook on the subject of Measurement and Evaluation in Education to gain efficiency at 80/80 and achieve better level of student's satisfaction.

\section{HYPOTHESIS}

Textbook on the subject of Measurement and Evaluation in Education had efficiency level at $80 / 80$ according to standard criteria and student's satisfaction level towards textbook on the subject of Measurement and Evaluation in Education was in high level. 
Populations used in this research was consisted of 2,450 students who were students of Suan Sunandha Rajabhat University in all years.

Target group used in this research on textbook on the subject of Measurement and Evaluation in Education was consisted of 250 students who were students of Suan Sunandha Rajabhat University in all years obtained by using purposive volunteer sampling.

\section{RELATED DOCUMENTS AND RESEARCHES}

Supeera [3] conducted a research on "Development of a Blended Model using Activity-Based Learning and a Think Pair Share Technique on a Wiki to Enhance the Creative Problem-Solving Ability of Ninth Grade Students" and concluded the results as blended learning model using activity-based learning and a think pair share technique on Wiki to enhance the creative problem-solving ability. This model consisted of 4 elements including: 1) instructional media; 2) learning management system; 3) communication; and 4) measurement and evaluation. There were 6 procedures as follows:

1) Objective establishment

2) Content teaching

3) Leading

4) Activities

5) Discussion

6) Presentation

The results revealed that students participated in experimental group significant had higher ability in solving problems creatively after testing average score than that before testing with statistical significance at .05 .

Sasithorn [4] conducted a research on "Development of an Activity-Based Learning Model Using an Educational Mobile Application Model to Enhance the Discipline of Upper Elementary School Students". The results revealed that developed model was consisted of 5 elements including: 1) educational mobile application model; 2) learning activities; 3) communication; 4) mobile communication device; and 5) evaluation.

There were 4 procedures as follows:

1) Motivation and experience building

2) Knowledge providing and practicing

3) Feedback

4) Assessment

Usanee Thepworachai [5] studied on Active Learning by Creating Active Learning Model of Nursing Education in Bachelor Degree and Higher Education and experimented with nursing students of Chulalongkorn University. From the study, it was found that active learning was another instructional method that was consistent with educational quality development. Nursing students became enthusiastic with better grades.

Robinson [6] studied on the use of Active Learning in biology classroom on problem solving, feedback, and learning-based instruction. The results revealed that students were able to apply problem solving to instructional activities, discuss with their groups, write layout, and participate in expressing their opinions. For atmosphere outside the classroom, students did their homework and exchanged their knowledge with their friends. The results of classroom activities led to systematical assessment whereas students were evaluated every week based on their works. The result of such assessment was considered as one of their final exam scores. Students understand and able to apply their obtained knowledge as well as able to analyze. Average pre-score was increased from $44 \%$ to be post-score at $77 \%$.

Fies [7] studied on classroom reaction of active learning. The results revealed that students had classroom reaction, discussion, and focus group whereas assessment on classroom hours spending in this active learning of students was averagely $80 \%$ of total classroom hours.

Graziano and Richard [8] studied on Business Imitation: Perception from Student's Experience and Active Learning Strategies for Business and Occupational Learning that was a mixed method research conducted by surveying and interviewing with the target group. From applying active learning strategies for business and occupational learning, it was found that students had better learning achievement and they were also enthusiastic to develop their knowledge and skills on working as well as business and occupational knowledge for future working.

Hammer [9] conducted a research on Participation in Active Learning, Learning Achievement, and Utilization Process of Online Technology in Communication and found that chatting via internet affected to learning achievement and utilization of online technology for communicating with other persons significantly caused students to participate in learning with better learning achievement.

Slavin [10] studied on Effects of Development of Classroom Active Learning and found that classroom active learning was effective causing students to learn qualitatively. After developing and implementing classroom active learning, teacher was able to improve their former instruction to be more efficient.

\section{DEFINITIONS}

1) Efficiency of textbook means capabilities of the lesson in building the learning achievement of the target students from Faculty of Education, SSRU in order to enable them to obtain learning according to determined criteria of $80 / 80$.

The former 80 means efficiency of processes evaluated from the student's scores obtained from doing practices of each lesson during the class that is averagely $80 \%$.

The latter 80 means efficiency of the result evaluated from the scores of students for their post-test that is averagely $80 \%$ ".

2) Satisfaction of students means the feeling of students toward learning by using textbook on the subject of Measurement and Evaluation in Education. This satisfaction was measured by using 10 items of Satisfaction Questionnaire upon the likert's 5 rating scales.

\section{RESEARCH FRAMEWORK AND CONCEPT}

Research framework and concept is shown in Fig. 1. 


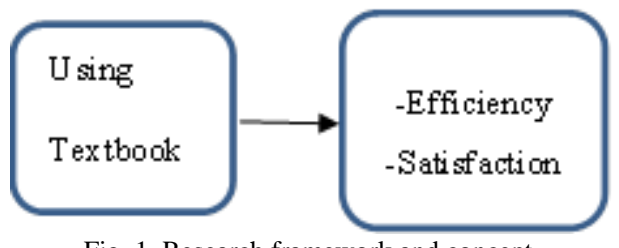

Fig. 1. Research framework and concept.

\section{RESEARCH PROCESS}

1) Studied papers and researches as well as studied from philosophers through interview and focus group in order to synthesize Measurement and Evaluation in Education.

2) Submit developed textbook on the subject of Measurement and Evaluation in Education to experts for inspection and improvement.

3) Tried out improved textbook on the subject of Measurement and Evaluation in Education with students who were not target group for further improvement and public relations.

4) Students who were target group studied created textbook on the subject of Measurement and Evaluation in Education and took pre and post test. Subsequently, satisfaction of students was evaluated after their usage of textbook on the subject of Measurement and Evaluation in Education.

4.1. Tested students with test review of 10 lessons. The obtained scores were collected as scores of formative evaluation.

4.2. 20 items of achievement test on textbook were tested with students and the obtained scores were collected as scores of post-test.

4.3. 10 items of satisfaction evaluation form towards textbook were commented by students.

5) The results were checked and the obtained scores of pre and post test were analyzed by using statistics in order to find efficiency at 80/80.

6) Student's satisfaction after using textbook on the subject of Measurement and Evaluation in Education was analyzed and concluded

\section{CONCLUSION}

1) From development and try out of textbook on the subject of Measurement and Evaluation in Education, it was found that it was suitable and efficient according to defined criteria calculated to be 81.50 / 82.00 when utilizing with 40 students who were target group that was consisted with defined hypothesis.

2) From try out of textbook on the subject of Measurement and Evaluation in Education, it was found that efficiency of process (E1) provided in tests was calculated to be $81.50 \%$ and efficiency of results ( E2 ) was calculated to be $82.00 \%$. These textbook on the subject of Measurement and Evaluation in Education had higher efficiency than $80 / 80$ as defined therefore it could be concluded that these textbook had high efficiency as defined by criteria and they were able to be used for classroom instruction efficiently.

3) From the results of student's satisfaction towards learning with textbook on the subject of Measurement and Evaluation in Education, it was found that overall student's satisfaction towards instruction using textbook was in the highest level, i.e., students had overall satisfaction towards textbook in high level with mean of 4.52 and item 10 was gained the highest satisfaction level of students. Average demand of students on creating textbook for other subjects was 4.84. For other evaluations, most of them had high level of satisfaction.

TABLE I: MEAN, STANDARD DEVIATION, AND SATISFACTION LEVEL OF STUDENTS TOWARDS TEXTBOOK ON THE SUBJECT OF MEASUREMENT AND EVALUATION IN EDUCATION

\begin{tabular}{|c|c|c|c|c|}
\hline Item & Assessment List & mean & S.D. & $\begin{array}{l}\text { Satisfaction } \\
\text { Level }\end{array}$ \\
\hline 1 & $\begin{array}{l}\text { Explanation of Measurement } \\
\text { and Evaluation in Education } \\
\text { was clear and } \\
\text { understandable. }\end{array}$ & 4.3 & 0.5 & High \\
\hline 2 & $\begin{array}{l}\text { Students understand contents } \\
\text { of the courses. }\end{array}$ & 4.3 & 0.6 & High \\
\hline 3 & $\begin{array}{l}\text { Procedures of Measurement } \\
\text { and Evaluation in Education } \\
\text { were clear and appropriate. }\end{array}$ & 4.78 & 0.56 & Highest \\
\hline 4 & $\begin{array}{l}\text { Lesson starter was } \\
\text { appropriate. }\end{array}$ & 4.5 & 0.61 & Highest \\
\hline 5 & $\begin{array}{l}\text { Activities were appropriate } \\
\text { and interesting. }\end{array}$ & 4.6 & 0.8 & High \\
\hline 6 & Conclusion was appropriate. & 4.73 & 0.56 & Highest \\
\hline 7 & $\begin{array}{l}\text { Students were the center with } \\
\text { participation. }\end{array}$ & 4.4 & 0.7 & High \\
\hline 8 & $\begin{array}{l}\text { Students were able to ask } \\
\text { what questions with teachers. }\end{array}$ & 4.27 & 0.69 & High \\
\hline 9 & $\begin{array}{l}\text { Tests and practices were } \\
\text { appropriate. }\end{array}$ & 4.5 & 0.65 & High \\
\hline 10 & $\begin{array}{l}\text { Students required } \\
\text { Measurement and Evaluation } \\
\text { in Education obtained from } \\
\text { textbook in other subjects. } \\
\text { Overall Assessment }\end{array}$ & 4.84 & 0.42 & Highest \\
\hline
\end{tabular}

From Table I, it was found that students who studied through textbook had high level of satisfaction with the mean of 4.52 and Standard Deviation of 0.61. Students required Measurement and Evaluation in Education obtained from textbook in other subjects. and they also had the highest level of satisfaction with the mean of 4.84 and Standard Deviation of 0.42 . When considering on each item, it was found that most students had satisfaction in high level.

\section{Discussion}

From development and utilization of textbook on the subject of Measurement and Evaluation in Education, the results could be discussed as follows:

Development and utilization of textbook was successful and efficient as expected because the research had studied on process of making textbook from several theories and concepts through studying on related papers and analyzing lesson's content from curriculum, determination of behavioral objective, planning of creation and development. Besides, the researcher was also supported by some content experts and their comments on index of consistency among 
issues, objectives, learning standard of curriculum, finding on accuracy of tools, and finding of confidence level, were assembled as a tool for creating and developing textbook on the subject of Measurement and Evaluation in Education. As a result, such textbook were able to be created and developed successfully. Besides, they were also able to be used and publicized to other instructors in other universities that was consistent with a research of Sunanta Suntornprasert [11] stated that instruction with textbook was able to develop students to be more confident with themselves and learn lessons with their potential leading to higher level of achievement. Besides, textbook also developed students in both cognitive domain and affective domain efficiently because they enabled students to learn and understand contents of lessons through repeated reading. Besides, it was also found that textbook were able to adjust learner's behavior to seek knowledge, realize, and see value of learning providing good cognitive skills to learners if such textbook were developed by content expert and expert on textbook correctly and systematically according to principles.

Efficiency of these textbook was in high level as expected at $81.50 / 82.00$ due to creation and development of such textbook. The researcher studied on basic data and analyzed work, contents, learners who were target group, and behavioral objectives prior planning on creation and development to meet those behavioral objectives under explanation and suggestions of content expert for inspecting accuracy of contents, language correctness, appropriateness of design, instructional methods, and presentation. Subsequently, the obtained lessons were improved, developed, and tried out with a small student group in order to find further faults for additional improvement and development prior performing field tryout with 40 students. The results showed that efficiency of textbook was 81.50 / 82.00 that was satisfying and met with expected hypothesis.

Student's satisfaction towards textbook on the subject of Measurement and Evaluation in Education was in high level for all items because the research studied on psychology of learning of learners before planning creation of textbook. Subsequently, the obtained results were planned for creation and development of complete textbook that was consistent with work of Chaiwat Waree [12] who studied on Application Development on Tablet to Promote a Classroom Research Skills for SSRU'Students. The results showed that the efficiency of application on tablet was at $80.77 / 81.82$ that was higher than defined criteria at 80/80. In addition, Overall satisfaction of students towards application on tablet usage was in the highest level.

\section{ACKNOWLEDGMENT}

This research was supported by Suan Sunandha Rajabhat University. Special thanks you to all experts and students of SSRU who helped and supported this project.

\section{REFERENCES}

[1] J. Sweller, Why Some Material Is Difficult to Learn, New York: Cognition and Instruction, 2006.

[2] J. Renne and M. Abraham, "The Necessity of each phase of the learning cycle in teaching high school physics," Journal of Research in Science Teaching, 2008, pp. 39-58.

[3] S. Davrueng, "Development of an integrated learning model using activity-based learning and peer-to-peer techniques to promote creative problem-solving ability for students in secondary education," Master Thesis Educational Technology and Communication Department of Educational Technology and Communication, Faculty of Education, Chulalongkorn University, 2012.

[4] S. Lichanporn and J. khlaysang, "Development of a learning-based learning model using educational applications on mobile devices to promote the discipline of elementary school students," An Online Journal of Education, 2014, pp. 13-26.

[5] U. Thepworachai, How to Teach Children How to Add Intelligence, Bangkok: Special Education Department, Srinakharinwirot University, 2000.

[6] R. F. Diano, "Active Learning in Large enrollment introductory biology class: problem soving, formative feedback, and teaching as learning," Thesis Ph.D Brigham Young University, United States, 2001.

[7] F. C. Hedwig, "Classroom response system: What do they add to an active learning environment?" Thesis Ph.D. The University of Texas at Austin, United States. 2005.

[8] G. Richard, "The virtual enterprise simulation: Students' perceptions of an experiential, active learning stratagem for business and career education," London: The United States of America, 2003.

[9] H. A .Vectoria, "The influence of interaction of active learning, learning outcomes and community bounding in an online technology course," Thesis Ed.D., The University of Cincinnati, Cincinnati, 2001.

[10] Slavin, Educational Psychology, N.P.: Johns Hopkins University, 2001.

[11] S. Suntornprasert, Guidelines for Creating Instructional Innovation and instructional Module, Ratchaburi : Thammarak Printing, 2004.

[12] C. Waree, "Application development on tablet to promote a classroom research skills for SSRU' students," Challenges and Solutions in Smart Learning, 2018, pp. 21-24.

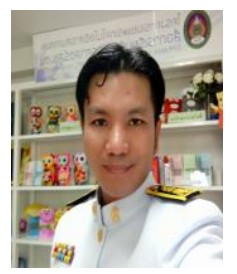

Chaiwat Waree was born in Nongchang, Thailand. He received the B.Ed. degree in Thai from the Srinakharinwirot University, TH, in 1999, the M.Ed. degree in guidance and counseling Psychology from the Srinakharinwirot University, TH, in 2002, the D.Ed degree in curriculum and instruction from the Burapha University, TH in 2010and the LL.B. degree in laws from Thammasat University, TH, in 2017.

His research interests cover the pedagogy and psychology and education technology and environment science.

Asst. Prof. Dr. Chaiwat is a lecturer at Faculty of Education, Suan Sunandha University and External assessor for Office of National Education Standards and Quality Assessment, TH. 